DOI: https://doi.org/10.24127/ajpm.v10i2.3669

\title{
IDENTIFIKASI PEMBELAJARAN MATEMATIKA PADA ANAK DIDIK LEMBAGA PEMBINAAN KHUSUS ANAK
}

\author{
Adi Slamet Kusumawardana ${ }^{1 *}$, Muhammad Islah Bebe Kewa ${ }^{2}$ \\ ${ }^{1 *, 2}$ Pendidikan Matematika, Universitas Muhammadiyah Malang \\ ${ }^{*}$ Corresponding author \\ E-mail: $\quad$ adikusuma@umm.ac.id ${ }^{\left.l^{*}\right)}$ \\ islahamabebe24@gmail.com $^{2)}$
}

Received 06 April 2021; Received in revised form 28 June 2021; Accepted 02 July 2021

\begin{abstract}
Abstrak
Salah satu sasaran pendidikan dan pembelajaran yang menjadi lahan besar proses pembinaan diri adalah LPKA atau Lembaga Pembinaan Khusus Anak. Penelitian ini bertujuan untuk mengetahui bagaimana pembelajaran matematika di LPKA Kelas 1 Kota Blitar dengan melihat dari tiga aspek yang akan diteliti yaitu motivasi belajar matematika, hasil test soal latihan, dan implementasi pelajaran matematika dalam kehidupan di LPKA. Adapun yang menjadi subjek penelitianya beberapa tingkat siswa di LPKA mulai dari SD-SMP- SMA dengan rincian 3 siswa SD, 6 Siswa SMP dan 6 Siswa SMA, serta guru mata pelajaran matematika pada setiap tingkatan. Metode penelitian menggunakan deskriptif kualitatif, dengan hasil pengumpulan data dari observasi dan wawancara untuk mengetahui keadaan dan kualifikasi pembelajaran matematika di LPKA Kelas 1 Blitar. Hasil penelitian dalam aspek motivasi belajar matematika anak didik di LPKA menunjukkan bahwa pada tingkat SD dan SMP berada pada tingkat kurang. Selanjutnya secara menyeluruh pada tingkat SMA termasuk dalam kategori cukup. Dalam aspek hasil test soal latihan anak didik, hanya 4 anak didik dari 15 anak didik yang mampu menyelesaikan test soal latihan meski membutuhkan aktifitas Scaffolding. Sementara dalam aspek implementasi pelajaran matematika dalam kehidupan sehari-hari hanya 3 anak dari 15 anak didik yang mampu menjelaskan keterkaitan antara matematika dengan kehidupan sehari-hari.
\end{abstract}

Kata kunci: Anak didik; LPKA kelas 1 Blitar; pembelajaran matematika.

\begin{abstract}
One of the targets of education and learning that becomes a big land of the self-development process is LPKA or Special Development Institute for Children. This study aims to find out how mathematics learning in LPKA Grade 1 Blitar city by looking at three aspects that will be studied, namely motivation to learn mathematics, test results of training questions, and implementation of mathematics lessons in life in LPKA. The subjects of his research were several levels of students in LPKA ranging from elementaryjunior high school ( 3 elementary students, 6 junior high schools students, and 6 high schools students) as well as teachers of math subjects at each level. The research method uses qualitative descriptive, with the results of data collection from observations and interviews described to find out the state and qualifications of mathematics learning in LPKA Grade 1 Blitar. The results of research in the motivational aspect of learning mathematics students in LPKA at the elementary level as a whole in the classroom are in the category of lack. While overall at junior high level is in the category of less. Furthermore, thoroughly at the high school level fall into the category of sufficient. In the aspect of the test results of the students' training, only 4 students out of 15 students were able to complete the test even though they needed Scaffolding activities from researchers. While in the aspect of the implementation of mathematics lessons in everyday life only 3 children out of 15 students are able to explain the relationship between mathematics and daily life.
\end{abstract}

Keywords: LPKA grade 1 Blitar; mathematics learning; students. 
DOI: https://doi.org/10.24127/ajpm.v10i2.3669

\section{PENDAHULUAN}

Pelajaran matematika adalah ilmu yang memiliki banyak peranan dan aplikasinya pada abad ke 21 kian terasa penting. Matematika dianggap menjadi mata pelajaran yang aplikasinya banyak digunakan dalam perkembangan teknologi dan kehidupan sehari - hari. Pembelajaran matematika dapat membentuk logika berpikir siswa dan bukan hanya tentang berhitung (Aisah et al., 2017; Ritonga \& Hasibuan, 2019). Aplikasi matematika selain ditemukan dalam ilmu kalkulasi di kehidupan sehari - hari, pada tingkat lanjut juga dapat berwujud logika matematika, logika pemrograman, kecerdasan buatan, dan teknologi pengenalan pola, sehingga matematika dianggap penting dalam pendidikan masyarakat baik sebagai untuk bekal dalam kehidupan sehari - hari maupun sebagai penunjang dalam karir dan pekerjaan. Maspupah dan Purnama (2020) menyatakan bahwa matematika merupakan ilmu yang membawa pengaruh dalam penguasaan siswa pada cabang ilmu yang lain, khususnya bidang sains seperti Fisika, Kimia, Biologi, Teknik, dan bahkan pada Bahasa inggris juga dapat ditemukan materi perhitungan matematika didalamnya. Oleh karena itu pelajaran matematika diajarkan pada banyak instansi pendidikan di Indonesia, yaitu di sekolah dan di luar sekolah. dan salah satu Lembaga pendidikan luar sekolah adalah pembinaan di Lembaga Pemasyarakatan Khusus Anak (Maspupah \& Purnama, 2020).

Penelitian sebelumnya menunjukkan bahwa pendidikan luar sekolah dihadirkan untuk menjawab kebutuhan dan tantangan dalam hidup yang semakin kompleks, serta tidak semua anak mampu mengenyam pendidikan dasar di sekolah formal. Meski demikian, pendidikan di luar sekolah tetap tak bisa dipisahkan dari sekolah formal, baik dari materi pelajaran maupun keterampilan yang diajarkan juga masih ada kaitan antara satu sama lain. Oleh karena itu Pelajaran matematika yang diajarkan di sekolah formal pun juga ditemukan pada sekolah non formal (Munawwir \& Nur Hanip, 2021; Widodo \& Soedjarwo, 2019). Pada pendidikan luar sekolah, khususnya di lembaga pemasyarakatan, narapidana di lokasi tersebut merupakan objek yang dibina dan diberi pelatihan tentang kerajinan seperti potong rambut, industri rumah tangga, elektronika, dan juga pelatihan penguatan akhlak agar selepas keluar dari Lembaga Pemasyarakatan. Hal serupa juga terjadi di lembaga pemasyarakatan anak, yang biasa disebut juga dengan lembaga pembinaan khusus anak (LPKA) dimana anak didik dibekali dengan pelajaran maupun pendidikan akhlak agar mendapat bekal dan dapat mengejar ketertinggalan dari pelajaran yang seharusnya mereka terima saat di sekolah (Supriyanto et al., 2019).

Anak didik yang terdapat di LPKA merupakan anak - anak yang menjalani tindakan dan menjalani pidana pada skala usia 12 - 18 tahun (Ahmad, 2019). Penelitian terkait LPKA yang telah dilakukan sebelumnya membahas tentang efek terapi Spiritual Emotional Freedom Technique (SEFT) untuk mengurangi tingkat agresifitas untuk anak didik di LPKA (Novitriani \& Hidayati, 2018). Penelitian lain juga pernah dilakukan untuk menggali perencanaan, pelaksanaan, dan kendala yang dihadapi dalam implementasi pendidikan formal pada LPKA Kota Bandung, dan hasil yang diperoleh adalah penyelenggaraan belum berjalan efektif dan efisien, serta upaya yang ditawarkan adalah dengan memperbaiki 
sistem kerjasama dengan sekolah dan menambah jam pelajaran (Sofyan \& Gunardi, 2020). Penelitian tentang penerapan pembelajaran Agama Islam juga pernah dilakukan pada LPKA sebagai usaha untuk meningkatkan akhlak anak didik di SMK Istimewa LPKA Tangerang. Dari hasil implementasi diperoleh ada peningkatan akhlak namun masih jauh dari maksimal, dikarenakan motivasi yang rendah dari sebagian besar siswa (Ginanjar, 2020).

Berdasarkan

penelitian sebelumnya yang telah dilakukan di beberapa LPKA di Indonesia Nampak belum ada yang membahas tentang identifikasi pembela-jaran matematika di LPKA khususnya pada aspek motivasi belajar dan implementasinya di kehidupan sehari - hari, padahal tujuan dari diberikannya bekal pendidikan kepada anak didik di LPKA adalah untuk mempersiapkan keterampilan dan pendidikan mereka di kehidupan pasca meninggalkan rumah tahanan, sehingga perlu untuk dikenalkan implementasi dari keterampilan dan pendidikan tersebut di kehidupan sehari - hari. Selain itu, penerapan pembelajaran matematika yang esensial dalam kehidupan sehari - hari juga perlu digali dan diidentifikasi.

Penelitian sebelumnya lebih banyak mengkaji implementasi pelatihan untuk peningkatan keterampilan, akhlak, dan membina mental anak - anak di LPKA dan belum pada implementasi pendidikan, khususnya pembelajaran matematika. Seperti telah diketahui pada penelitian sebelumnya bahwa pada pembelajaran Agama Islam saja penerapannya kurang maksimal dikarena-kan motivasi pada sebagian besar siswa masih kurang, tentunya hal serupa terjadi juga pada pembelajaran matematika yang tingkat kesulitannya lebih sukar daripada pembelajaran agama Islam. identifikasi pada pembelajaran matematika juga perlu untuk membahas tentang bagaimana pelaksanaan di LPKA dan tes latihan yang diberikan kepada anak didik disana. Dari penelitian sebelumnya juga nampak bahwa LPKA yang belum pernah diteliti adalah pada LPKA Blitar, padahal pada LPKA Kota Blitar terdapat klasifikasi untuk menentukan kelas dan tingkatan pendidikan yang akan dijalani oleh anak didik selama menjalani pembinaan di LPKA.

Berdasarkan paparan diatas, maka perlu untuk diidentifikasi pembelajaran matematika bagi anak didik di LPKA Kota Blitar, mulai dari tingkat SD hingga SMA. Berangkat dari hal tersebut, maka tujuan dari penelitian ini adalah mengidentifikasi bagaimana pembelaja-ran matematika di LPKA Kota Blitar yang dilihat dari tiga aspek yaitu motivasi belajar anak didik, hasil tes latihan soal, dan implementasi pelajaran matematika dalam kehidupan sehari - hari anak didik di LPKA. Hasil yang diharapkan dari penelitian ini berupa deskripsi kemampuan anak didik ditinjau dari aspek tersebut.

\section{METODE PENELITIAN}

Penelitian ini menggunakan pendekatan kualitatif dengan jenis penelitian deskriptif. Penelitian dilaksanakan di Lembaga Pembinaan Khusus Anak Kelas 1 Kota Blitar. Penelitian berlangsung dari Hari Senin tanggal 28 September 2020 hingga Hari Senin tanggal 9 Oktober 2020 dengan tetap mentaati protokol kesehatan. Subjek pada penelitian ini terdiri dari 2 subjek yaitu Guru matematika dan Siswa pada masing-masing jenjang pendidikan, dengan rincian 3 anak didik SD, 6 anak didik SMP dan 6 anak didik SMA. 
Pemilihan ini mempertimbangkan lama masa pidana yang sudah ditempuh anak didik yaitu anak didik yang sedang/telah menjalani masa pidana lebih dari satu semester. Objek penelitian ini adalah pembelajaran matematika di LPKA Kelas 1 Blitar.

Alur penelitian dimulai dari pengumpulan data menggunakan observasi dan wawancara. Setelah data terkumpul selanjutnya menyusun dan menampilkan data yang didapat di lapangan. Selanjutnya melakukan reduksi data dan penyajian data baik dalam bentuk tabel ataupun deskripsi. Data yang sudah didapatkan kemudian dianalisis dan melakukan pembahasan. Langkah terakhir memfomulasikan isi kesimpulan sebagai jawaban dan rumusan masalah serta saran dan rekomendasi.

Teknik pengumpulan data menggunakan observasi dan wawancara. Observasi dilakukan ketika proses pembelajaran sedang berlangsung didalam kelas. Observasi dilakukan untuk mengumpulkan data dari aktivitas guru dan anak didik didalam kelas dan mengikuti jadwal pembelajaran matematika yang telah berlaku. Wawancara dilakukan kepada anak didik dan guru mata pelajaran di luar proses pembelajaran secara bergilir. Setelah proses pembelajaran didalam kelas, anak didik yang menjadi subjek penelitian mengikuti sesi wawancara. Pada sesi ini dilakukan test latihan soal kepada anak didik yang menjadi subjek penelitian. Setiap anak didik diberikan satu soal latihan kepada anak didik dengan materi yang sedang dipelajari didalam kelas.

Pada penelitian ini menggunakan beberapa instrumen penelitian diantaranya a). Pedoman wawancara yang berisi beberapa pertanyaan pokok untuk memperoleh informasi terkait pembelajaran matematika anak didik di LPKA yang dilihat dalam 3 aspek. Aspek motivasi belajar, hasil test latihan soal dan implementasi pembelajaran matematika dalam kehidupan seharihari. Pertanyaan ditujukan kepada narasumber yaitu Guru Matematika dan anak didik LPKA Kelas 1 Blitar. b) Pedoman observasi terdiri dari dua yaitu lembar observasi untuk aktivitas anak didik dan lembar observasi untuk aktivitas guru.

Tabel 1. Indikator dan item observasi motivasi belajar anak didik

\begin{tabular}{|c|c|}
\hline Indikator & $\begin{array}{c}\text { Item Observasi } \\
\text { Anak Didik } \\
\end{array}$ \\
\hline $\begin{array}{l}\text { Kuatnya } \\
\text { kemauan untuk } \\
\text { berbuat }\end{array}$ & $\begin{array}{l}\text { - Anak didik aktif } \\
\text { memperhatikan } \\
\text { penjelasan guru } \\
\text { dalam kegiatan } \\
\text { pembelajaran } \\
\text { - Anak didik } \\
\text { mencatat materi } \\
\text { yang } \\
\text { disampaikan oleh } \\
\text { guru }\end{array}$ \\
\hline $\begin{array}{l}\text { Ketekunan } \\
\text { dalam } \\
\text { mengerjakan } \\
\text { tugas }\end{array}$ & $\begin{array}{l}\text { Anak didik aktif } \\
\text { berdiskusi } \\
\text { dengan teman- } \\
\text { temannya dalam } \\
\text { menyelesaikan } \\
\text { tugas } \\
\text { - Anak didik tekun } \\
\text { dalam } \\
\text { memecahkan } \\
\text { masalah yang } \\
\text { diberikan guru }\end{array}$ \\
\hline $\begin{array}{l}\text { Menunjukkan } \\
\text { minat terhadap } \\
\text { matematika }\end{array}$ & $\begin{array}{l}\text { - Anak didik } \\
\text { bersemangat } \\
\text { dalam } \\
\text { mempelajari } \\
\text { matematika } \\
\text { - Anak didik aktif } \\
\text { bertanya kepada } \\
\text { guru }\end{array}$ \\
\hline
\end{tabular}


Data hasil observasi digunakan untuk melihat observasi belajar, hasil test latihan soal dan implementasi matematika dalam kehidupan seharihari. Dalam penelitian ini terdapat indikator yang digunakan untuk mengklasifikasi tingkatan motivasi belajar anak didik. Indikator tersebut kemudian dimuat dalam item-item observasi untuk melihat motivasi belajar anak didik. Indikator tersebut dapat dilihat pada Tabel 1.

Hasil observasi motivasi belajar anak didik yang diperoleh kemudian akan didistribusikan dalam rentangan nilai yaitu nilai 26-30 kategori sangat baik, nilai 21-25 kategori baik, nilai 1620 cukup, nilai 11-15 Kurang, nilai $\leq 10$ sangat kurang (Afriani et al., 2020). c).

Instrumen soal latihan digunakan untuk melihat aspek hasil test latihan soal sehingga akan terlihat juga kemampuan anak didik yang menjadi subjek penelitian. Pengerjaan soal latihan untuk anak didik pada setiap jenjang dan menjadi subjek penelitian dilakukan saat proses wawancara berlangsung, dengan setiap anak didik diberikan satu latihan soal. Soal-soal latihan ini diambil dari materi-materi yang sedang dipelajari anak didik pada setiap kelas dan jenjang. Sementara untuk teknik analisis data dilakukan dengan runtutan sebagai berikut :

1. Pengumpulan data dilakukan agar data-data hasil penelitian dikumpulkan

2. Mereduksi data hasil wawancara dan observasi, bertujuan untuk pemusatan perhatian dari data hasil wawancara dan observasi yang masih umum, sehingga terfokus pada permasalahan penelitian.

3. Verifikasi data dilakukan dengan cara mendengarkan kembali hasil wawancara dengan subjek penelitian dengan mencocokannya dengan hasil wawancara yang telah ditulis, serta mencocokkan hasil observasi dilapangan dengan hasil wawancara dengan subjek penelitian.

4. Perumusan kesimpulan dilakukan untuk peninjauan terhadap kebenaran dari penyimpulan, berkaitan dengan kesesuaian dan konsistensinya dengan judul, tujuan dan perumusan masalah.

\section{HASIL DAN PEMBAHASAN}

Secara umum, dari pengamatan yang dilakukan, proses pembelajaran matematika di LPKA pada setiap jenjang pendidikan menggunakan kurikulum, silabus dan Rencana Pelaksanaan Pembelajaran (RPP) yang sama dengan sekolah induk masingmasing. Metode pembelajaran yang sering digunakan adalah metode ceramah partisipatoris, dengan media pembelajaran yang digunakan beupa buku ajar, papan tulis dan spidol. Hasil penelitian yang ditemukkan dalam pembelajaran matematika bagi anak didik di LPKA kelas 1 Blitar dilihat dari beberapa aspek yang diantaranya motivasi belajar matematika, hasil tes soal latihan, dan implementasi pelajaran matematika dalam kehidupan seharihari. Pada aspek motivasi belajar, dari hasil analisis data observasi aktivitas anak didik didapat data pada Tabel 2.

Tabel 2. Skor motivasi belajar matematika

\begin{tabular}{cccc}
\hline $\begin{array}{c}\text { Tingkatan } \\
\text { Pendidikan }\end{array}$ & Kelas & $\begin{array}{c}\text { Skor } \\
\text { Motivasi } \\
\text { Belajar }\end{array}$ & Kategori \\
\hline SD & VI & 14 & Kurang \\
\hline \multirow{2}{*}{ SMP } & VII & 15 & Kurang \\
& VIII & 14 & Kurang \\
& IX & 17 & Cukup \\
\hline \multirow{3}{*}{ SMA } & X & 19 & Cukup \\
& XI & 15 & Kurang \\
& XII & 19 & Cukup \\
\hline
\end{tabular}


Dari Tabel 2 terlihat bahwa skor motivasi belajar anak didik pada tingkat SD sebesar 14 dan skor ini berada pada rentang nilai kategori kurang. Jika ditinjau kembali pada indikator motivasi belajar yang dipaparkan sebelumnya, motivasi belajar anak didik pada tingkat SD belum mencapai indikator ketekunan dalam mengerjakan tugas dan indikator menunjukkan minat terhadap matematika.

Sementara pada tingkat SMP didapat total skor dari setiap kelas dengan rincian: kelas VII sebesar 15 termasuk kategori kurang, kelas VIII sebesar 14 termasuk dalam kategori kurang dan kelas IX sebesar 17 termasuk dalam kategori cukup. Hal ini menunjukkan tingkat motivasi belajar anak didik pada tataran SMP berada pada kategori kurang.

Selanjutnya pada tingkat SMA diperoleh total skor dari setiap kelas dengan rincian : kelas $\mathrm{X}$ sebesar 19 termasuk dalam kategori cukup, kelas XI sebesar 15 termasuk dalam kategori kurang dan kelas XII sebesar 19 termasuk dalam kategori cukup. Hal ini menunjukkan tingkat motivasi belajar anak didik pada tataran SMA berada pada kategori cukup. Kemudian dari hasil wawancara dengan 15 anak didik yang menjadi subjek penelitian, hanya 5 anak didik yang meiliki ketertarikan untuk mempelajari matematika namun dengan syarat bahwa anak didik harus didampingi langsung oleh guru. Kelima anak didik tersebut berasal dari 1 anak didik tingkat SD, 2 anak didik tingkat SMP, dan 2 anak didik tingkat SMA.

Setelah menelaah aspek Motivasi, kemudian dari sudut pandang aspek hasil test soal latihan anak didik disetiap jenjang pendidikan dan kelas diperoleh hasil bahwa dari 15 anak didik yang menjadi subjek penelitian hanya 4 anak didik yang mampu mengerjakan soal test sesuai tingkatan masing-masing namun dalam proses pengerjaan ke-empat anak tersebut harus sambil dituntun. Ke-empat anak didik tersebut berasal dari 2 anak didik tingkat SMP dan 2 anak didik tingkat SMA.

Aspek terakhir yang diteliti dalam penelitian ini adalah implementasi pelajaran matematika dalam kehidupan sehari-hari anak didik di LPKA. Dari 15 anak didik yang menjadi subjek penelitian hanya 3 anak didik yang mampu menjelaskan implementasi pelajaran matematika dalam kehidupan sehari-hari. . Ke-tiga anak didik tersebut berasal dari 1 anak didik tingkat SD, 1 anak didik tingkat SMP, dan 1 anak didik tingkat SMA. Sementara hasil observasi dan wawancara kepada guru dari setiap jenjangnya ditemukkan bahwa guru pengampu pelajaran matematika pada semua tingkatan mulai dari SD SMP dan SMA sudah melakukan beberapa upaya dalam menstimulus anak didik.

Berbicara pada aspek motivasi belajar anak didik di LPKA, guru memiliki peran penting dalam menumbuhkan dan menstimulus anak didik agar memiliki motivasi belajar. Vani Rahmayani menjelaskan dalam penelitiannya di tahun 2020 bahwa pelajaran matematika memiliki sifat abstrak yang tidak mudah untuk dapat dipahami oleh semua siswa. Hal itu membuat motivasi siswa dalam belajar matematika semakin berkurang. Guru matematika sebaiknya melakukan strategi khusus bagi anak yang memiliki motivasi rendah dalam belajar matematika seperti menggunakan metode dan kegiatan yang beragam, jadikan siswa peserta aktif, ciptakan suasana kelas yang kondusif, libatkan diri untuk membantu siswa dalam 
mencapai hasil, hindari kompetisi antarpribadi, antusias dalam mengajar, pemberian penghargaan untuk memotivasi, ciptakan aktivitas yang melibatkan seluruh siswa dalam kelas, hindari penggunaan ancaman, dan jangan menjadi guru yang ditakuti oleh siswa (Rahmayani, 2020).

Suwanto dalam penelitiannya di tahun 2020 mengindikasikan bahwa pengunaan model pembelajaran Teams Games Tournaments (TGT) pada peserta didik kelas XII IPA 2 SMA Negeri 1 Karangrayung Semester 2 dapat meningkatkan motivasi belajar dan hasil belajar matematika khususnya materi Barisan dan Deret Bilangan. (Siti Aisah \& Wicanti, 2020; Suwanto, 2020). Kemudian Ulya dalam penelitiannya juga menjelaskan bahwa pembelajaran dengan pendekatan kontekstual lebih secara signifikan dibandingkan dengan permbelajaran konvensional dalam meningkatkan kemampuan koneksi matematis siswa dan motivasi belajar siswa. Terdapat hubungan positif antara kemampuan koneksi matematis dan motivasi belajar (Iik Faiqotul Ulya, Riana Irawati, 2016).

Pada aspek hasil tes soal latihan untuk anak didik ditemukkan bahwa perlunya tindakan Scaffolding terhadap anak didik saat proses pembelajaran matematika. Scaffolding dapat berupa bantuan seperti pemeragaan contoh, pemberian petunjuk atau kata kunci dengan memancing siswa untuk menemukan penyelesaiannya sendiri, maka scaffolding ini dapat mengurangi kesulitan siswa dalam memahami pembelajaran khususnya pelajaran matematika. Scaffolding dapat meningkatkan pemahaman konsep dan motivasi dari siswa serta dapat membuat siswa menjadi lebih mandiri dalam belajar. Penggunaan scaffolding dalam proses pembelajaran dengan kasus yang ditemui adalah ketidakmampuan siswa dalam menyelesaikan soal cerita. Pada saat menyelesaikan soal, siswa tidak mampu memahami masalah, tidak mampu menyebutkan apa yang diketahui, kesalahan dalam melakukan operasi matematika, tidak mampu menentukan rumus, dan tidak mampu melakukan perhitungan secara logis. Namun setelah diberikannya scaffolding dengan menggunakan reviewing, explaining dan restructuring, siswa mampu mengatasi kesalahan-kesalahan dalam menyelesaikan soal cerita serta tidak lagi terjadi kesalahan dan kesulitan dalam menyelesaikan masalah. Sejalan dengan itu, Eprilianti menjelaskan penelitiannya tentang beberapa bentuk scaffolding yang bisa diterapkan dalam pembelajaran matematika misalnya dapat berupa bantuan seperti pemeragaan contoh, pemberian petunjuk atau kata kunci dengan memancing siswa untuk menemukan penyelesaiannya sendiri, maka scaffolding ini dapat mengurangi kesulitan siswa dalam memahami pembelajaran khususnya pelajaran matematika (Wahyu Epriliyanti, 2017).

Sementara aspek implementasi pelajaran matematika dalam kehidupan sehari-hari anak didik di LPKA dijelaskan bahwa kemampuan ini merupakan bagian dari kemampuan koneksi matematis. Seperti yang dijelaskan Muhammad Daut Siagian dalam penelitiannya menyebutkan bahwa Koneksi matematis merupakan suatu keterampilan yang harus dibangun dan dipelajari, karena dengan kemampuan koneksi matematis yang baik akan membantu peserta didik untuk dapat mengetahui hubungan berbagai konsep dalam matematika dan mengaplikasikan matematika dalam kehidupan sehari-hari. Dengan 
kemampuan koneksi matematis siswa akan merasakan manfaat dalam mempelajari matematika, dan kemelekatan pemahaman siswa terhadap konsep yang dipelajarainya akan bertahan lebih lama (Siagian, 2016).

Sementara itu, Siti Riyadhotul Janah, Hardi Suyitno, Isnaini Rosyida menyebutkan hal lain yang bisa mempengaruhi kemampuan anak didik dalam mengimplementasikan pelajaran matematika dalam kehidupan seharihari. Dalam penelitiannya menyebutkan bahwa literasi matematika merupakan kemam-puan seseorang untuk merumuskan, menggunakan dan menginterpretasikan matematika dalam berbagai konteks pemecahan masalah kehidupan sehari-hari secara efektif sehingga literasi matematis sangat diperlukan dalam kehidupan sehari-hari karena menjadi salah satu kunci untuk menghadapi masyarakat yang terus berubah (disrupsi). Kemampuan guru dalam menghubungkan ilmu dengan dunia nyata dilakukan dengan melatih siswa dengan soal-soal matematika yang berhubungan dengan kehidupan sehari-hari (Janah et al., 2019).

Dari pelaksanaan di LPKA, diperoleh temuan bahwa anak didik tidak memiliki ketertarikan terhadap pelajaran matematika yang berdampak pada sulitnya memahami materi dan rumus yang disampaikan oleh guru. Guru pengampuh mata pelajaran matematika disetiap jenjang juga mengatakan bahwa hal ini juga dikarenakan daya tangkap anak didik yang lemah sehingga cepat lupa dengan materi, hal ini sejalan dengan penelitian Supriyanto et. al, tahun 2019 bahwa pada pendidikan agama Islam juga ditemukan bahwa motivasi belajar siswa teramat rendah dan cepat lupa dengan materi (Supriyanto et al., 2019), meskipun pada pembelajaran mate- matika sudah ditunjang oleh ketiga guru pengampu mata pelajaran matematika dari setiap jenjang pendidikan, dalam hasil wawancara dan observasi aktivitas guru sudah melakukan upaya dan memainkan perannya sebagai motivator dalam memberikan motivasi dan pengutan kepada anak didik dalam mempelajari matematika.

Dari aspek pelaksanaan pengerjaan soal tes tersebut diperoleh temuan bahwa ada kebutuhan khusus dan perhatian lebih kepada anak didik dalam pengerjaan soal tes tersebut sehingga mereka bisa mengerjakan soal tes tersebut. Ini berarti untuk pengerjaan soal perlu bantuan dan perhatian lebih terhadap anak didik atau biasa yang disebut dengan scaffolding. Temuan ini mengindikasinya perlu perhatian praktisi pendidikan untuk mengembangkan pembelajaran yang sesuai dengan kebutuhan anak didik di LPKA yang tentunya berbeda dengan anak didik di sekolah dan pendidikan formal serta hal ini salah satu upaya agar siswa di LPKA tetap mendapat hak pendidikan layaknya anak didik di pendidikan formal (Budijanto, 2013).

berdasarkan hasil wawancara dengan anak didik didapat bahwa anak didik masih kurang dalam mengimplementasikan pelajaran matematika dalam kehidupan sehari-hari. Kurangnya aktivitas ini dikarenakan ketidakpahaman dan ketidakmampuan anak didik dalam mengaitkan materi dengan kehidupan sehari-hari. Hal ini sebenarnya dapat diprediksi berdasarkan motivasi dan ketertarikan anak didik yang rendah. Selaras dengan penelitian sebelumnya bahwa motivasi yang rendah berdampak pada pemahaman tentang materi matematika, sehingga ketika motivasi rendah, begitu juga dengan implementasi materi dalam kehidupan sehari - hari. 
Kelebihan penelitian dibandingkan dari penelitian sebelumnya dalam bentuk identifikasi kondisi motivasi dan pembelajaran dari semua strata pendidikan yang ada di LPKA, sementara penelitian sebelumnya hanya membahas tentang pelatihan keterampilan dan pendidikan pada tingkat SD (Evi, 2011; Karim, 2011). Meski demikian, keterbatasan penelitian ini masih belum mengukur, menguji coba, dan berupaya meningkatkan motivasi serta pemahaman anak didik melalui media pembelajaran untuk guru agar sesuai dengan kemampuan masingmasing siswa. Meski demikian hasil penelitian ini dapat mendeskripsikan kondisi anak didik di LPKA dan kebutuhannya agar dapat menerima pendidikan yang lebih baik, karena secara teori anak didik di LPKA dating dengan permasalahan serta butuh dibina agar dapat menjalani kehidupan yang lebih dan memiliki kecakapan serta karir yang lebih baik. Mereka juga diharapkan dapat mengaplikasikan keterampilan yang telah diajarkan di LPKA ke kehidupan mereka pasca pembinaan dan tentunya dapat melanjutkan pendidikan ke jenjang yang lebih tinggi (Kiswoyowati, 2011; Razkia et al., 2021; Safitri \& Leonardi, 2013).

\section{KESIMPULAN DAN SARAN}

Kesimpulan yang didapat dari penelitian ini bahwa hasil identifikasi pembelajaran matematika untuk anak didik di LPKA yang ditinjau dari aspek motivasi belajar, hasil tes latihan soal, dan implementasi pelajaran matematika dalam kehidupan sehari - hari anak didik di LPKA memperoleh hasil bahwa ditinjau dari aspek motivasi kondisinya secara umum motivasi anak didik SD masih kurang, anak didik SMP secara umum kurang, dan hanya pada kelas IX yang terkategori cukup, serta motivasi pada anak didik SMA secara umum cukup baik. Lebih lanjut, dari 15 anak didik yang menjadi subyek penelitian, hanya 4 anak didik yang mampu menyelesaikan soal tes latihan dan masih membutuhkan aktifitas tambahan berupa scaffolding. Selain itu dari 15 siswa, hanya 3 anak yang mampu menjelaskan keterkaitan antara matematika dengan kehidupan sehari hari. Dari hasil tersebut, kurangnya motivasi siswa disebabkan baik dari anak didik yang memang membutuhkan perhatian khusus dan guru yang mengalami kesulitan dalam mentransformasikan materi.

Saran untuk penelitian selanjutnya agar dapat melakukan penelitian serupa dengan dilengkapi penyampaian materi secara personal kepada siswa dan juga dapat dilanjutkan dengan melakukan penelitian terkait model, media, atau metode pembelajaran yang lebih efektif di pembelajaran matematika pada LPKA.

\section{DAFTAR PUSTAKA}

Afriani, D., Folastri, S., \& Syahputra, Y. (2020). Efektivitas Layanan Bimbingan Kelompok dalam Peningkatan Motivasi Belajar Siswa di SMKN 59 Jakarta. Psychocentrum Review, 2(2). https://doi.org/10.26539/pcr.22356

Ahmad, G. (2019). Hakikat Pendidikan Di Lembaga Pembinaan Khusus Anak. Journal ISTIGHNA, 1(1), 42-59.

https://doi.org/10.33853/istighna.v $1 \mathrm{i} 1.17$

Aisah, I., Fadilah, F. N., \& Suyudi, M. (2017). Aplikasi logika matematika pada aljabar untaian dna dalam proses hibridisasi. Jurnal Sigma$M u, 9(2)$. 
Budijanto, O. W. (2013). Pemenuhan Hak Pendidikan Bagi Anak Didik Pemasyarakatan di Lembaga Pembinaan Khusus Anak. Jurnal Ilmiah Kebijakan Hukum, 7(1).

Evi, S. (2011). Pendekatan Matematika Realistik (PMR) untuk Meningkatkan Kemampuan Berfikir Siswa di Tingkat Sekolah Dasar. Jurnal Penelitian Pendidikan, Edisi Khus(2).

Ginanjar, M. H. (2020). Learning Integration of Islamic Education for ex-prison Children at SMK Istimewa Tangerang Banten. Jurnal Pendidikan Islam, 8(2). https://doi.org/10.14421/jpi.2019.8 2.223-238

Iik Faiqotul Ulya, Riana Irawati, and M. (2016). Peningkatan Kemampuan Koneksi Matematis Dan Motivasi Belajar Siswa Menggunakan Pendekatan Kontekstual. Jurnal Pena Ilmiah, 1(1), 121-130. https://doi.org/10.23819/pi.v1i1.29 40

Janah, S. R., Suyitno, H., \& Rosyida, I. (2019). Pentingnya Literasi Matematika dan Berpikir Kritis Matematis dalam Menghadapi Abad ke-21. PRISMA, Prosiding Seminar Nasional Matematika, 2.

Karim, A. (2011). Penerapan Metode Penemuan Terbimbing Dalam Pembelajaran Matematika Untuk Meningkatkan Pemahaman Konsep Dan Kemampuan Penalaran. Jurnal Penelitian Pendidikan, Edisi Khus(2).

Kiswoyowati, A. (2011). Pengaruh motivasi belajar dan kegiatan belajar siswa terhadap kecakapan hidup siswa. Jurnal Penelitian Pendidikan, Edisi Khus(1).

Maspupah, A., \& Purnama, A. (2020). Analisis Kesulitan Siswa MTs
Kelas VIII Dalam Menyelesaikan Soal Cerita Sistem Persamaan Linear Dua Variabel (SPLDV) Ditinjau Dari Perbedaan Gender. Jurnal Cendekia: Jurnal Pendidikan Matematika, 4(1). https://doi.org/10.31004/cendekia. v4i1.193

Munawwir, A., \& Nur Hanip, S. P. (2021). Sekolah Pesisi Juang: Pendidikan Non-Formal Anak Pesisir. Jurnal Pendidikan Nonformal, 16(1). https://doi.org/10.17977/um041v16 i1p1-11

Novitriani, A., \& Hidayati, F. (2018). Pengaruh Spiritual Emotional Freedom Technique terhadap SelfAcceptance Warga Binaan di Lembaga Pemasyarakatan Perempuan. Psympathic: Jurnal Ilmiah Psikologi, 5(1). https://doi.org/10.15575/psy.v5i1.2 322

Pradestya, R., Imswatama, A., \& Siti Balkist, P. (2020). Analisis Kemampuan Kognitif Pada Langkah-Langkah Pemecahan Masalah Ditinjau Dari Kecerdasan Logis-Matematis. Symmetry: Pasundan Journal of Research in Mathematics Learning and Education, volume 5. https://doi.org/10.23969/symmetry. v5i1.1723

Rahmayani, V. R. A. (2020). Strategi Peningkatan Motivasi Siswa Dalam Pembelajaran Matematika Di Kelas. Journal On Teacher Education, 2(1), 18-24.

Razkia, D., Safitri, A., \& Santoso, S. (2021). Menemukan makna hidup dengan Forgiveness, Studi Pada Siswa Binaan Remaja Di Lembaga Pemasyarakatan Anak. Psychopolytan: Jurnal Psikologi, 4(2). 
DOI: https://doi.org/10.24127/ajpm.v10i2.3669

https://doi.org/10.36341/psi.v4i2.1 530

Ritonga, R. P. Y., \& Hasibuan, L. R. (2019). Pembelajaran Analogi Untuk Membentuk Sikap dan Moral Siswa Pada Konsep Logika Matematika. JURNAL EDUSCIENCE, 6(2). https://doi.org/10.36987/jes.v6i2.1 533

Safitri, R. M., \& Leonardi, T. (2013). Hubungan antara Disonansi Kognitif dengan Keterlibatan Siswa dalam Menempuh Pendidikan Formal di Lembaga Pemasyarakatan Anak Blitar. Jurnal Psikologi Klinis Dan Kesehatan Mental, 03(02).

Siagian, M. D. (2016). Kemampuan koneksi matematik dalam pembelajaran matematika. MES: Journal of Matematics Education and Science 2, 2(1).

Siti Aisah, L., \& Wicanti, I. (2020). Meningkatkan Hasil Belajar Matematika Siswa Menggunakan Model Pembelajaran Teams Games Tournaments (Tgt) Pada Materi Trigonometri. Mathline: Jurnal Matematika Dan Pendidikan Matematika, 5(2), 172-182.

https://doi.org/10.31943/mathline.v $5 \mathrm{i} 2.158$

Sofyan, I., \& Gunardi, K. (2020). Implementasi Pendidikan Formal bagi Anak yang Berkonflik dengan Hukum di Lembaga Pembinaan Khusus Anak Kelas II Bandung. Jurnal Socius: Journal of Sociology Research and Education, $7(1)$. https://doi.org/10.24036/scs.v7i1.1 73
Supriyanto, S., Wahidin, U., \& Ginanjar, M. H. (2019). Implementasi Sistem Pembelajaran Pendidikan Agama Islam Bagi Narapidana Muslim Di Pesantren Al-Hidayah Lembaga Pemasyarakatan Kelas Ii a Kota Bogor Tahun 2019. Prosa PAI: Prosiding Al Hidayah Pendidikan Agama Islam, 2(1B), 186-201. http://jurnal.staialhidayahbogor.ac. id/index.php/ppai/article/view/572

Suwanto, E. (2020). Matematika Menggunakan Model Teams Games Tournaments ( Tgt ) Pada Peserta Didik Xii Ipa 2 Sma N 1 Karangrayung. IJRP: Internasional Jurnal Riset, 1(1), 1-8.

Wahyu Epriliyanti, L. (2017). Pengaruh Kecerdasan Logis Matematis Dan Spasial-Visual Terhadap Hasil Belajar Matematika Siswa Smp. MATHEdunesa, 6(2).

Widodo, W., \& Soedjarwo, S. (2019). Analisis Kebutuhan Pendidikan Non Formal di Sekolah. ... Nasional \& Tети Kolegial Jurusan PLS 